\title{
Asymptomatic hemilateral pneumothorax and pneumomediastinum following surgical tracheostomy in a patient with hyponatremia and zolpidem withdrawal delirium
}

\author{
Yoshihiro Takasugi, Risa Aoki and Shota Tsukimoto
}

Keywords: Tracheostomy, Pneumothorax, Pneumomediastinum, Delirium, Hyponatremia

\section{To the editor}

Pneumothorax following tracheostomy is a rare complication, with a reported incidence of approximately $1 \%$ following both open surgical and percutaneous tracheostomy $[1,2]$, but potentially life-threatening complication. Post-tracheostomy pneumothorax can usually be diagnosed by clinical signs and symptoms even before a postoperative chest film is obtained. We report a case of asymptomatic pneumothorax and pneumomediastinum following tracheostomy in an adult patient with delirium, but was diagnosed by radiographic examinations of the next day.

\section{Case presentation}

A 59-year-old man was admitted to our acute care unit due to persistent intraoral bleeding following extraction of a wisdom tooth. The patient habitually took $20 \mathrm{mg} /$ day of zolpidem, imidazopyridine class of $\gamma$-aminobutyric acid A $\left(\mathrm{GABA}_{\mathrm{A}}\right)$ receptor agonist, often taking more than $50 \mathrm{mg} /$ day. Laboratory tests indicated hyponatremia (Na $123 \mathrm{mEq} / \mathrm{L}$, serum osmolality $256 \mathrm{mOsm} / \mathrm{L}$ ) secondary to the syndrome of inappropriate secretion of antidiuretic hormone (SIADH) (ADH $45.3 \mathrm{pg} / \mathrm{mL})$. At the time of admission, he mumbled in delirium and developed generalized tonic seizures twice.

At $11 \mathrm{~h}$ after his admission, he vomited approximately $200 \mathrm{~mL}$ of clot and blood, and $\mathrm{SpO}_{2}$ decreased to $80 \%$;

\footnotetext{
* Correspondence: dzc01654@nifty.com

Department of Anesthesiology, Kindai University Faculty of Medicine, 377-2 Ohno-higashi, Osaka-sayama, Osaka 589-8511, Japan
}

since aspiration due to intraoral bleeding was suspected, emergency hemostasis and tracheostomy for postoperative respiratory management were performed. Two hours later, $\mathrm{SpO}_{2}$ was $100 \%$ with $5 \mathrm{~L} / \mathrm{min}$ oxygen through the tracheostomy mask. We continuously infused 3\% hypertonic saline and administered fosphenytoin and diazepam for treatment of hyponatremia and generalized tonic seizures, respectively. With this treatment, hyponatremia improved and generalized tonic seizures were relieved, while delirium and confusion lasted.

On the second hospital day, he complained of pain in his head and neck together with mild dyspnea $\left(\mathrm{SpO}_{2} 95-\right.$ 96\% with $2 \mathrm{~L} / \mathrm{min}$ oxygen). Hemilateral pneumothorax, pneumomediastinum, and subcutaneous emphysema were diagnosed by chest X-ray and CT images of the thorax and neck, for which a chest tube was inserted (Fig. 1). On the seventh hospital day, CT images indicated disappearance of the pneumothorax and remission of subcutaneous emphysema and pneumomediastinum, and the chest tube was removed. On the ninth hospital day, his consciousness and communication normalized and he was discharged on the twelfth hospital day.

\section{Discussion}

The diagnosis of post-tracheostomy pneumothorax is usually based on clinical signs and symptoms, such as sudden and acute chest pain, dyspnea, tachycardia, decreased breath sounds and oxygen desaturation, and routine use of post-tracheostomy chest radiography has currently been reported as unnecessary in adults [3-5]. In this case, when tension pneumothorax and pneumomediastinum 


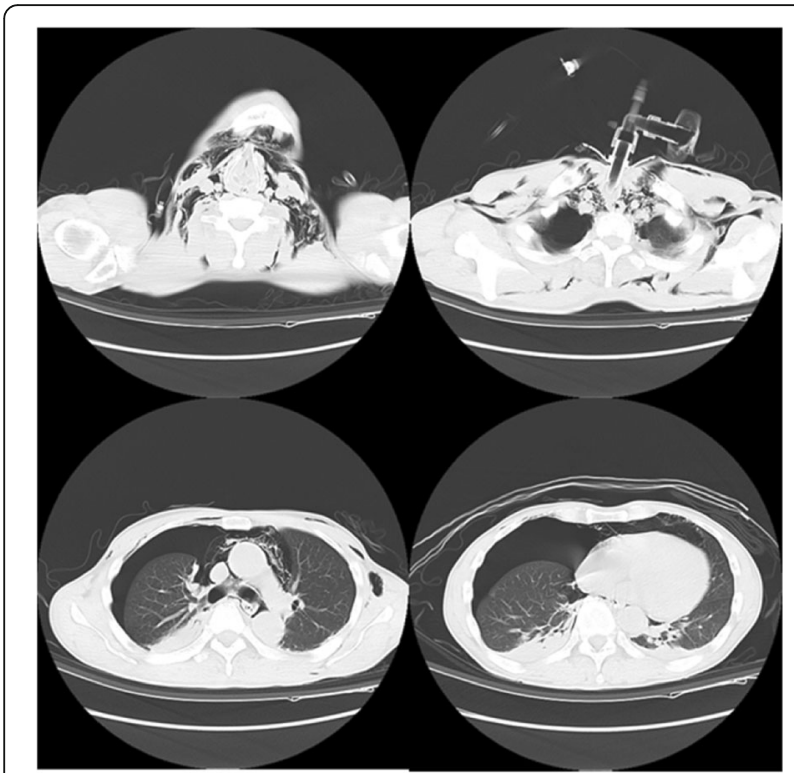

Fig. $1 \mathrm{CT}$ images of the neck and thorax on the day following tracheostomy. CT images revealed emphysema of the chest, neck and mediastinum, and pneumothorax of the right lung

were diagnosed by chest X-ray and CT examinations, the patient did not have any of the usual features of both pneumothorax and pneumomediastinum; he only complained of pain in his head and neck, and his $\mathrm{SpO}_{2}$ was 95-96\% while breathing $2 \mathrm{~L} / \mathrm{min}$ oxygen. Symptoms of hyponatremia and zolpidem withdrawal include delirium, confusion, disorientation, and seizures [6, 7]. Patients with delirium exhibit symptoms of disturbances in consciousness, orientation, memory, perception, and behavior: tactile hallucinations in patients with delirium may involve paresthesia and pain [8]. We assumed that our patient's sensory disturbance associated with the delirium may have resulted in the absence of clinical signs of tension pneumothorax.

\section{Conclusion}

The current case suggests that postoperative radiographic examinations may have a role to play in the early diagnosis of pneumothorax and pneumomediastinum in patients with delirium.

\section{Abbreviations}

ADH: Antidiuretic hormone; $C T$ : Computed tomography; GABA $A_{A}$ YAminobutyric acid A; SIADH: Syndrome of inappropriate secretion of antidiuretic hormone; $\mathrm{SpO}_{2}$ : Percutaneous oxygen saturation

\section{Acknowledgements}

Not applicable.

\section{Funding}

None.

Availability of data and materials Not applicable.

\section{Authors' contributions}

YT wrote the manuscript as the corresponding author. YT and RA conducted anesthetic management to the patient. ST and RA participated in laboratory data collection and drafted the article. All authors read and approved the final manuscript.

Ethics approval and consent to participate Not applicable.

\section{Consent for publication}

Written informed consent was obtained from the patient for publication of this case report and any accompanying images.

\section{Competing interests}

The authors declare that they have no competing interests.

\section{Publisher's Note}

Springer Nature remains neutral with regard to jurisdictional claims in published maps and institutional affiliations.

Received: 9 January 2018 Accepted: 14 March 2018

Published online: 03 April 2018

\section{References}

1. Panajaroen P, Tangjaturonrasme N. Pneumothorax after tracheostomy: a prospective study. Otolaryngol Pol. 2015;69:26-30.

2. Fikkers BG, van Veen JA, Kooloos JG, Pickkers P, van den Hoogen FJ, Hillen B, van der Hoeven JG. Emphysema and pneumothorax after percutaneous tracheostomy: case reports and an anatomic study. Chest. 2004;125:1805-14.

3. Hamburger MD, Wolf JS, Berry JA, Molter D. Appropriateness of routine postoperative chest radiography after tracheotomy. Arch Otolaryngol Head Neck Surg. 2000;126:649-51.

4. Tobler WD Jr, Mella JR, Ng J, Selvam A, Burke PA, Agarwal S. Chest X-ray after tracheostomy is not necessary unless clinically indicated. World J Surg. 2012;36:266-9.

5. Swanson GJ, Meleca RJ, Bander J, Stachler RJ. The utility of chest radiography following percutaneous dilational tracheotomy. Arch Otolaryngol Head Neck Surg. 2002;128:1253-4.

6. Liappas IA, Malitas PN, Dimopoulos NP, Gitsa OE, Liappas Al, Nikolaou ChK, Christodoulou GN. Zolpidem dependence case series: possible neurobiological mechanisms and clinical management. J Psychopharmacol. 2003;17(1):131-5.

7. Aragona M. Abuse, dependence, and epileptic seizures after zolpidem withdrawal: review and case report. Clin Neuropharmacol. 2000;23:281-3.

8. Cole MG. Delirium in elderly patients. Am J Geriatr Psychiatry. 2004;12:7-21.

\section{Submit your manuscript to a SpringerOpen ${ }^{\circ}$ journal and benefit from:}

- Convenient online submission

Rigorous peer review

- Open access: articles freely available online

- High visibility within the field

- Retaining the copyright to your article

Submit your next manuscript at $\gg$ springeropen.com 